\title{
Which Yields with Wastes? Study on Pilot of the Efficiency of Water Treatment Plant- Case of the Sector of Algerian Tanning
}

\author{
Mohamed Necer, Rachid Smail \\ Research Laboratory in Industrial Prevention (LARPI) - Health and Safety Institute, University of Batna, \\ Batna, Algeria \\ Email: necermohamed@yahoo.fr
}

Received 31 August 2014; revised 28 September 2014; accepted 21 October 2014

Copyright (C) 2014 by authors and Scientific Research Publishing Inc.

This work is licensed under the Creative Commons Attribution International License (CC BY).

http://creativecommons.org/licenses/by/4.0/

(c) (i) Open Access

\begin{abstract}
Tannery industries generate wastewater containing high concentrations of sulfur. Most of wastes are liquid (effluent). The river section and tanning are the source of most tannery waste. Dehairing is a process of separation of hair and epidermis. Lime and sulfides are used for this process. Thus, sulfur in wastewater dehairing occurs as sulfide. Today, catalysis is at the centre of major societal concerns about energy, environment and sustainable development. The discovery of new catalytic processes and the improvement of existing ones are also critically important for improving the quality of life while simultaneously reducing the adverse impact of human activities on the environment. With a substitution approach of a catalyst $\mathrm{MnSO}_{4}$ by multiple wastes from tannery and the metallurgical sector, this study investigated the recycle of waste from dehairing process and waste from metallurgical industry. The results indicated $32 \%$ of oxidized sulfur for the first waste derived from process of depilation and $30 \%$ for the second waste from metallurgical process industry. A preliminary cost analysis demonstrated that the proposed solution is much cheaper than the discharging of waste and wastewater in a WWTP; however, the sustainability of the proposed solution provided a second alternative, to alleviate the operational costs of installations wastewater from tanneries, without significantly impacting the environment.
\end{abstract}

\section{Keywords}

Substituent, Environment, Tannery, Waste

\section{Introduction}

Tannery is an industry with strong potential of pollution. The incidences upon the environment which it is ad-

How to cite this paper: Necer, M. and Smail, R. (2014) Which Yields with Wastes? Study on Pilot of the Efficiency of Water Treatment Plant-Case of the Sector of Algerian Tanning. Journal of Water Resource and Protection, 6, 1457-1463. 
visable to take into account understand not only the charges and the concentration of the traditional pollutants, but also the use of certain chemicals. Water is mixed with organic matter (proteins, peptides, and amino, acid acids fatty, sulfur and trivalent chromium). They are highly polluted [1]. The majority of operations use and consume several chemical products. The animal skin is subjected to deferent process to eliminate meat, lipids and the hairs. This stage uses different chemicals products (in particular: hydroxide of sodium, hypochlorite of sodium, dichromate of potassium, lime, chlorides, sulphuric acid, formic acid, tensioactifs, sulphide of sodium, salts of sodium and ammonium, etc.). The obtained skin is then handled by $\mathrm{Cr}^{3+}$ or by the plant tannins, the mineral salts and the coloring agents to obtain leather [2]. The used products end in waste water with a clear contribution in polluting load. These operations are carried out in aqueous environment, therefore generate water pollution. The tannery waste water pollution has two sources [3]: Skin and Chemical reactive used in the various operations.

Without water purification (dysfunction of the installations) and in the absence of an effective technology of recovery, the unit loses annually on one hand:

- $140 \mathrm{kilogram} /$ day of chromium with their prices with $1.22 € / \mathrm{kg}$, are equivalent to $51879.77 € /$ year;

- $162.4 \mathrm{kilogram} /$ day of sulfides with their prices with $0.3 € / \mathrm{kg}$, are equivalent to $16577.76 € /$ year.

This heavy heritage of industry consuming water and import chemicals, the managers are forced to exert a responsibility. Management that implies, for example, to know well the chemicals implemented in the process (including the very prepared products). To take the safety measures for the protection of people, the environment and finally optimizes the operation of the waste water treatment installations in order to answer the multiple requirements and environmental stakes, social and economic [3]. Waste management and environmental protection are mandatory requirements of modern society. Nevertheless these treatments installations of polluting water represent an unbearable because of the high cost of operation (chemical, energy, maintenance).

On the other hand in Algeria, the steel industry activity's generates an important production of industrial waste (slag) which raises a problem of storage and pollution. Following the example of industrial nations this product, presents a plentiful raw material or low cost. Who must be exploited on a large scale in operations "sometimes without interest for the administrators" for example the operations of waste water treatment [4] [5].

The purpose of this research is to choose among the existing waste that can be reused. Within the framework of the application of the best available techniques, the goal is double: reusing waste and substitution with other products used in processes.

\section{Material and Methods}

\subsection{Analysis of the Waste Water}

\subsubsection{Points of Taking}

Several campaigns of data collecting were led to the exit of the stages of production, and at the level of the pond of collection where moved towards all the waste water generated by the company. Two modes data collecting are adopted:

Immediate grips and average samples constituted by the mixture of several collect distributed throughout the day at the rate of a collecting per hour.

\subsubsection{Analyzed Parameters}

Sulfur and other chemical parameters were analyzed according to the normalized (standardized) methods AFNOR [6].

\section{Experimental Study of the Effectiveness of the Station}

To study the effectiveness of purification station of the unit by the new substituent, we carried out a partner of taking away of basic effluents (rejection between 6 A.M and 10 A.M of the morning) and acid (rejection between 10 A.M and 14 P.M), starting from the gutters of collection.

However, the objective of our partner was obtaining representative data collecting with an aim of being able to study on pilot the effectiveness of the station, and for this reason we based ourselves on the principal operations of purification, namely the desulfurization and precipitation of chromium. 


\subsection{Desulfurization}

\subsubsection{Principle}

The elimination of sulfur contained in water of river, is carried out by oxidation with contribution of air according to reaction, refer to "(1)"

$$
2 \mathrm{~S}^{2-}+2 \mathrm{O}_{2}+\mathrm{H}_{2} \mathrm{O} \rightleftarrows \mathrm{S}_{2} \mathrm{O}_{3}+2 \mathrm{OH}^{-}
$$

Thus the sulfur will be transformed into thiosulfate. The Pourbaix curves clearly show the distribution of the species of sulfur according to the $\mathrm{pH}$ and the potential (see Figure 1) [5].

\subsubsection{Procedure}

To desulphurize the effluents of pre-hardening and hardening, a volume of effluent is collected at the end of the operations chain containing considerable quantities of sulfur. The rejections will be oxidized one taking account certain necessary parameters for the optimization of desulfurization results: (contribution of oxygen $\left(\mathrm{O}_{2}\right)$, mechanical agitation, time):

- Firstly: A contribution of air, during 3 hours using a compressor (a volume of anti-foamer is added to the reaction to avoid the foam formation which could obstruct the good diffusion of the air and thus the transfer of oxygen in water.

- Secondly: Then by agitation during 3 hours, using a surface aerator (propeller electro-agitator);

- Thirdly: Then a volume of manganese sulphate adds some $\mathrm{MnSO}_{4}$ (catalyst to be substituted there after by the ferrous waste of the iron and steel industry) used to obtain a complete and more rapid.

\subsubsection{Experimental Results}

Initial volume of effluent $=464 \mathrm{mg} / \mathrm{l}$.

\subsubsection{Interpretation of the Results}

The test and the proportioning of sulfur by ferricyanides of potassium show us that the elimination of sulfur by oxidation to the air in the presence of catalyst $\mathrm{MnSO}_{4}$ gives excellent results. Elimination of $99.43 \%$ of sulfur (refer to Graphics 1-3). These results will be taken as means of comparison with the results of the substitute (ferrous waste resulting from the activity of iron and steel industry). The results obtained, show us that the treatment of desulphurization envisaged is very effective. However the reaction time and the operating conditions must be well controlled (parameters). The study on pilot of the influence of these parameters with use of $\mathrm{MnSO}_{4}$ like catalyst, gives us the results (see Table 1 and Table 2).

Indeed the results obtained, show us clearly and allow us to say that the best desulfurization is carried out by oxidation with contribution of air, and that simple agitation without contribution of air will not be enough to in any case with the desulfurization of the effluent ensures. But the frequent use of $\mathrm{MnSO}_{4}$ costs very expensive to the company (product of importation) and that always presents a charge leather for the industry.

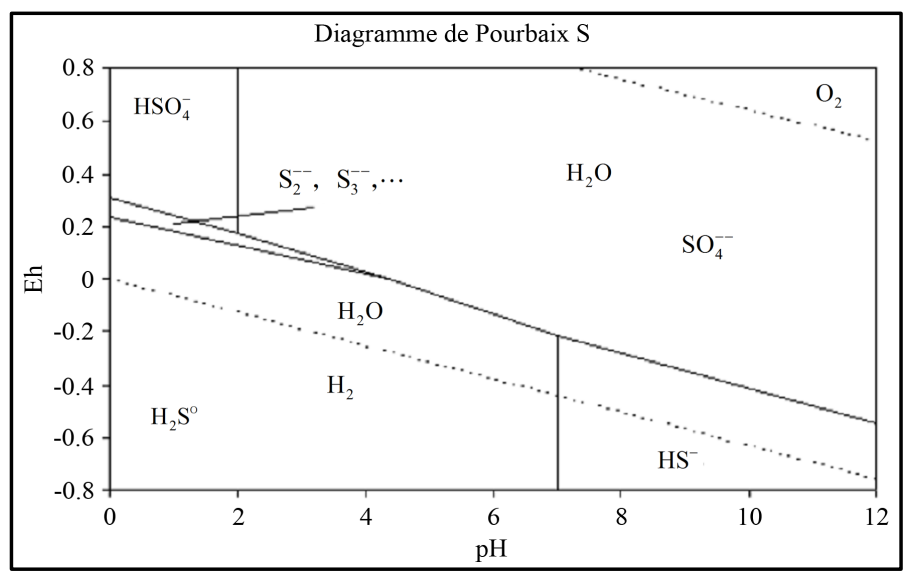

Figure 1. Diagram of steady balances tension-PH of sulfur-water system, at $25^{\circ} \mathrm{C}[5]$. 


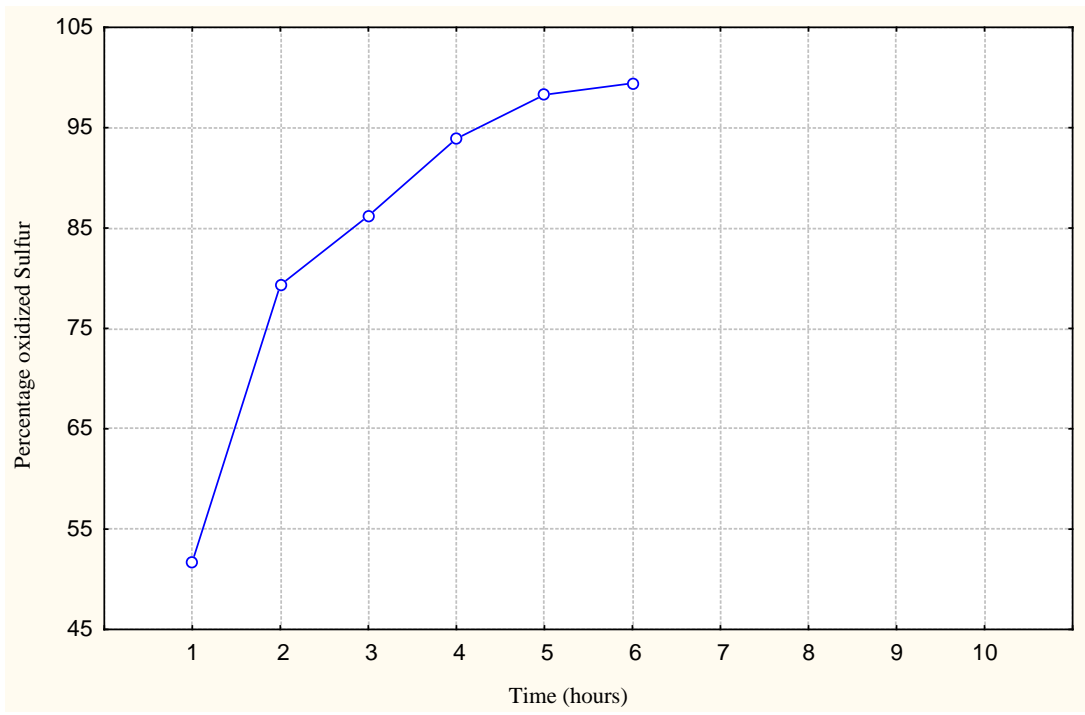

Graphic 1. Percentage of oxidized sulfur (with $2 \mathrm{ml} \mathrm{MnSO}_{4}$ ).

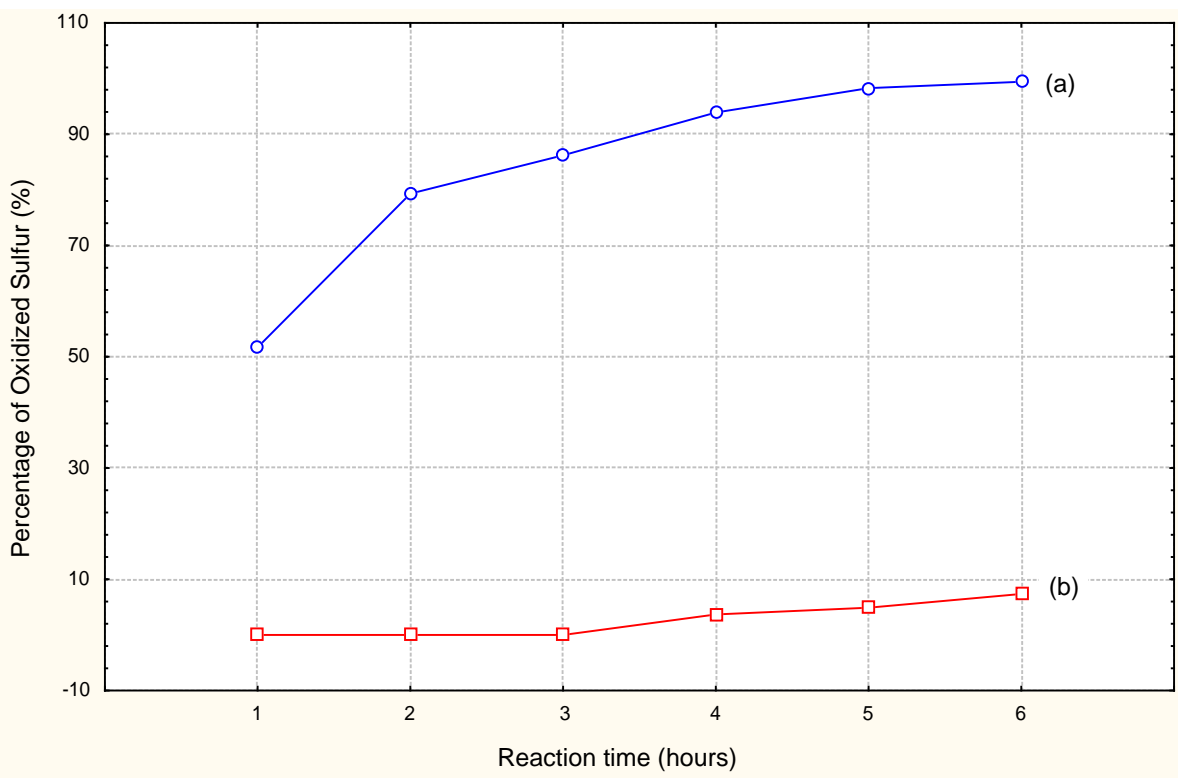

Graphic 2. Comparison of the desulfurization results with (2 $\mathrm{ml}$ of $\mathrm{MnSO}_{4}$ ). (a) With variation parameters (Contribution of air and agitation); (b) Without variation parameters (without contribution of air agitation).

\subsubsection{Test of Substitution of the $\mathrm{MnSO}_{4}$ Catalyst}

\section{1) Objectives:}

In order to decrease the importation of the products and thus to reduce the very high cost in currency for the leather company on the one hand, to find other exits for waste of another company of other share. We carried out tests of substitution of one of the products used in the station of waste water treatment (catalyst sulphate $\mathrm{MnSO}_{4}$ manganese) by another product (ferrous waste resulting from the iron and steel industry) available in Algeria and from which the chemical characteristics are not very different from that of catalyst used. The product used for substitution is $\mathrm{FeSO}_{4}$.

While being based on the fact that this product, when is oxide is become oxidants very strong and can thus take part in the oxidation of sulfur and replace catalyst envisaged $\mathrm{MnSO}_{4}$.

2) Experimental results of substitution: 


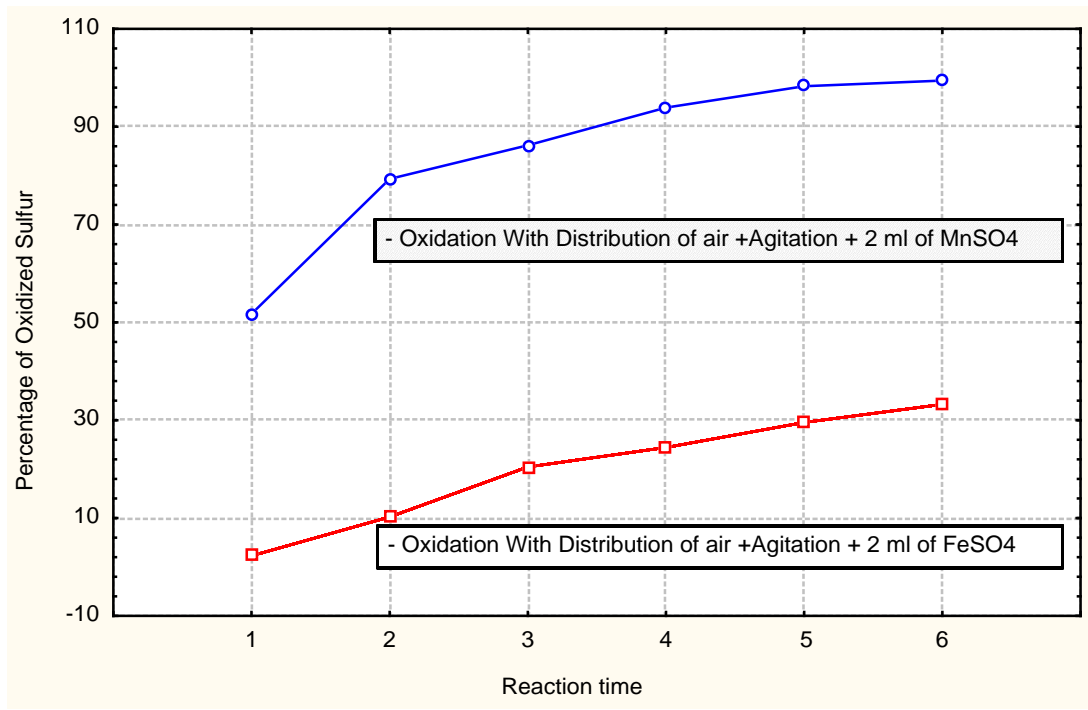

Graphic 3. Comparison of the results of percentage desulphurized sulfur.

Table 1. Percentage of oxidized sulfur (with $2 \mathrm{ml} \mathrm{MnSO}_{4}$ ).

\begin{tabular}{cc}
\hline Time (hours) & Percentage oxidized sulfur (with parameters variation) \\
\hline First hour & $51.73 \%$ \\
Second hour & $79.32 \%$ \\
Third hour & $86.21 \%$ \\
Fourth hour & $93.91 \%$ \\
Fifth hour & $98.28 \%$ \\
Sixth hour & $99.43 \%$ \\
\hline
\end{tabular}

Table 2. Comparison between the desulfurization results $-2 \mathrm{ml} \mathrm{MnSO}_{4}$ without and with parameters variation.

\begin{tabular}{ccc}
\hline Time (hours) & $\begin{array}{c}\text { Percentage oxidized sulfur } \\
\text { (with parameters variation) }\end{array}$ & $\begin{array}{c}\text { Percentage oxidized sulfur } \\
\text { (without parameters variation) }\end{array}$ \\
\hline First hour & $51.73 \%$ & $0.0 \%$ \\
Second hour & $79.32 \%$ & $0.0 \%$ \\
Third hour & $86.21 \%$ & $0.0 \%$ \\
Fourth hour & $93.91 \%$ & $3.68 \%$ \\
Fifth hour & $98.28 \%$ & $4.90 \%$ \\
Sixth hour & $99.43 \%$ & $7.36 \%$ \\
\hline
\end{tabular}

For the oxidation of sulfur with use of the $\mathrm{FeSO}_{4}$ catalyst (Table 3 and Table 4).

- Test: $10 \mathrm{ml}$;

- Sulfur concentration: $2816 \mathrm{mg} / \mathrm{l}$.

\section{Discussion}

From the tests on pilot, it arises that the $\mathrm{MnSO}_{4}$ catalyst used for the oxidation of sulfur definitely more effective and in conformity than the ferrous sulphate $\mathrm{FeSO}_{4}$ compared here to ferrous waste of the iron and steel sector. 
Table 3. Desulfurization with distribution of air and low of $\mathrm{FeSO}_{4}=0.41$ $\mathrm{ml} /$ hour + agitation.

\begin{tabular}{ccc}
\hline Time (hours) & Sulfur concentration & Percentage oxidized sulfur \\
\hline First hour & 2608 & $0 \%$ \\
Second hour & 2608 & $0 \%$ \\
Third hour & 2608 & $0 \%$ \\
Fourth hour & 2512 & $3.68 \%$ \\
Fifth hour & 2480 & $4.90 \%$ \\
Sixth hour & 2416 & $7.36 \%$ \\
\hline
\end{tabular}

Table 4. Desulfurization without distribution of air and flow of $\mathrm{FeSO}_{4}=2$ $\mathrm{ml} /$ hour + agitation

\begin{tabular}{ccc}
\hline Time (hours) & Sulfur concentration & Percentage oxidized sulfur \\
\hline First hour & 2752 & $2.27 \%$ \\
Second hour & 2528 & $10.23 \%$ \\
Third hour & 2240 & $20.45 \%$ \\
Fourth hour & 2128 & $24.43 \%$ \\
Fifth hour & 1984 & $29.54 \%$ \\
Sixth hour & 1860 & $33.24 \%$ \\
\hline
\end{tabular}

That could be the consequence proportion of iron which precipitates neighbors $\mathrm{pH}$ from 4.6 to 6 and thus does not take part has the oxidation of sulfur, whereas that of sulfur takes part has close $\mathrm{pH}$ has 8 . The Pourbaix curves also inform us about this aspect of appearance of new species according to the $\mathrm{pH}$ [7]. We agree has to also say that better results can be obtained by increasing the concentration of the substituent (ferrous waste) in the effluent of the tannery and by also increasing the reaction time of desulfurization. The solution proposed could be used as springboard for possible reflection for the complex problems of companies which note that their sustainability is threatened because of the loads which can be to relieve by rational solutions. The companies has great possibilities of preserving the natural environment and of minimizing it the economic losses, by, on the one hand, the application of the concept of substitution and or recycling of waste valuable and on the other hand by a management responsible for all under systems for the company (station of purification for example). Finally, at least as far as general Environmental management systems, is concerned, the environmental policy of an enterprise must include a commitment to preventing pollution. In the United States, the common term for the body of knowledge, approaches, techniques, practices, and technologies aimed at minimizing the creation of pollution is "pollution prevention", or "P2". Terms often used as near synonyms for P2 are "waste minimization" and "clean production". Together these terms sum [8].

\section{Conclusion}

Stricter legal limits on sulfur levels require measures to reduce their value in the wastewater final tannery. Removal of wastewater containing high sulfur concentrations contributes significantly to the overall effluent. However, the final sulfate concentration in the tannery wastewater is still too high to meet future standards. Separate results remain low, 32\% for waste from the tannery, and 30\% for the waste from the steel industry. But the sum of the results of the two waste give better results desulfurization, or $60 \%$ of oxidized sulfur. The companies have great possibilities of minimizing the economic losses, and to preserve the natural environment. The review of EU waste legislation offers the chance to revolutionize the way we think about and deal with waste. Turning waste into a valuable resource should be among the cornerstones of a resource-efficient in world. However, this will require combining ambitious targets with intelligent policy tools and rigorous application. Tannery 
industry shows a clear example of what can be gained if we succeed. Substitution by waste also underscores the enormous potential of waste to make a positive contribution to the environment and society as a whole.

\section{Acknowledgements}

The authors would like to thank Kamel Eddine BOUHIDEL and Hamel Benmoussa for their support and contribution to the work.

\section{References}

[1] Barrett, G.C. and Elmore, D.T. (2004) Amino Acids and Peptides. Cambridge University Press, Cambridge.

[2] Suthanthararajan, R., Ravindranath, E., Chitra, K., Umamaheswari, B., Ramesh, T. and Rajamam, S. (2004) Membrane Application for Recovery and Reuse of Water from Treated Tannery Wastewater. Desalination, 164, 151-156.

[3] Tamersit, S. (2009) Tannery Waste Water and Tanneries Water Recycling and Recovery of Pollutants Baths Deharing. Memory Magister, Batna University, Batna.

[4] Rouabah, K., Zergua, A., Beroual, A. and Guetteche, M.N. (2013) Recovery and Use of Blast Furnace Slag in the Field of Road Construction in Algeria. Open Journal of Civil Engineering, 3, 113-118.

[5] Pourbaix, M. (1963) Atlas Electro Chemical Equilibrium at $25^{\circ} \mathrm{C}$. Gauthier-Villard \& $\mathrm{C}^{\mathrm{ie}}$, Paris, $551 \mathrm{p}$.

[6] AFNOR (1999) The Quality of Water, Environment Series. French Association for Standardization, Paris.

[7] Gal, J.Y. and Persin, M. (1986) Exercise Programs and Analysis of Chemical Reactions in Solution. Dunod University, Paris, 174.

[8] Cheremisinoff, N.P. and Bendavid-Val, A. (2001) Green Profits. The Manager's Handbook for ISO 14001 and Pollution Prevention. Elsevier, Amsterdam. 
Scientific Research Publishing (SCIRP) is one of the largest Open Access journal publishers. It is currently publishing more than 200 open access, online, peer-reviewed journals covering a wide range of academic disciplines. SCIRP serves the worldwide academic communities and contributes to the progress and application of science with its publication.

Other selected journals from SCIRP are listed as below. Submit your manuscript to us via either submit@scirp.org or Online Submission Portal.
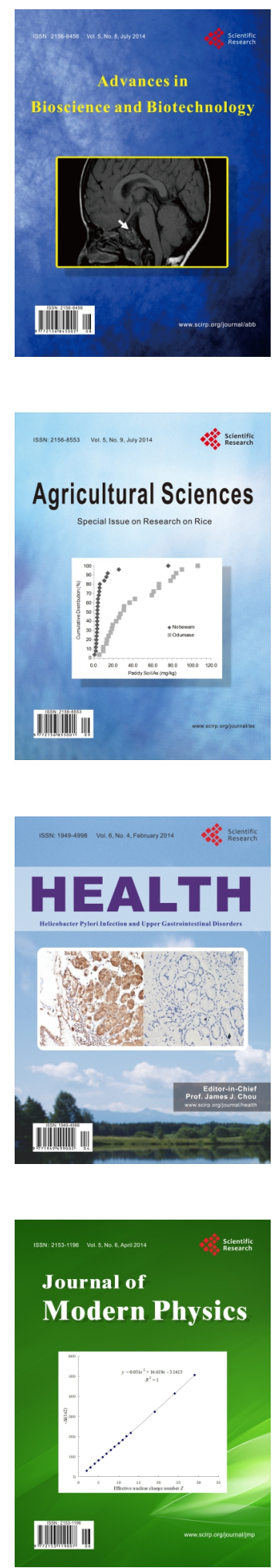
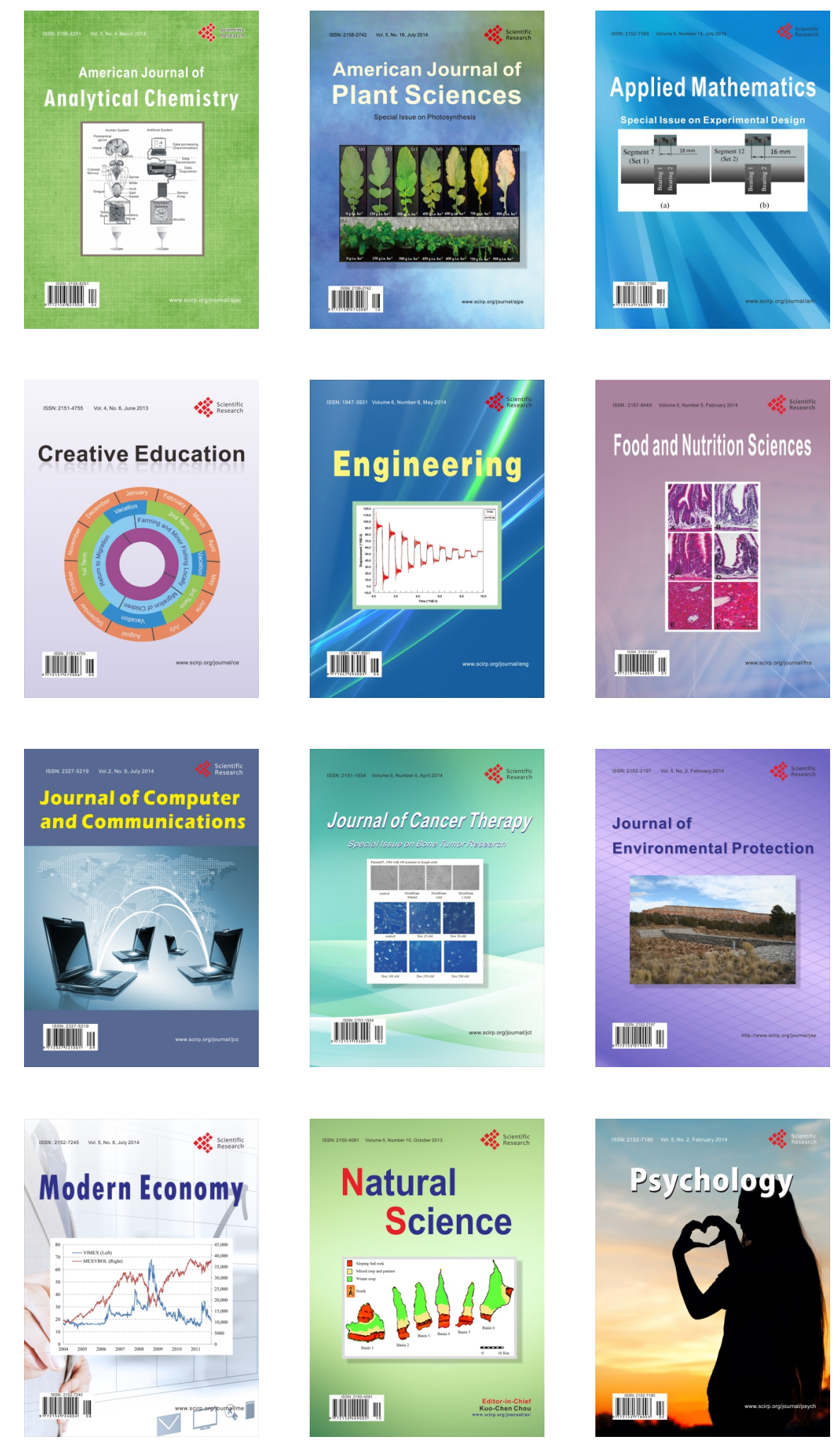